Article

\title{
Germination Ecology of Brachiaria eruciformis in Australia and Its Implications for Weed Management
}

\author{
Ahmadreza Mobli ${ }^{1,2, *} \mathbb{D}$, Mahboobeh Mollaee ${ }^{1,2} \mathbb{D}$, Sudheesh Manalil ${ }^{2,3}$ and \\ Bhagirath Singh Chauhan $2 \mathbb{D}$ \\ 1 Department of Agrotechnology, Faculty of Agriculture, Ferdowsi University of Mashhad, Mashhad \\ 91775-1163, Iran; m.mollaee@uq.edu.au \\ 2 The Centre for Crop Science, Queensland Alliance for Agriculture and Food Innovation (QAAFI), \\ The University of Queensland, Gatton, 4343 Queensland, Australia; s.manalil@uq.edu.au (S.M.); \\ b.chauhan@uq.edu.au (B.S.C.) \\ 3 Amrita School of Agricultural Sciences, Amrita Vishwa Vidyapeetham, Coimbatore 641112, India \\ * Correspondence: a.mobli@uq.edu.au; Tel.: +98-(51)-38805000
}

Received: 29 November 2019; Accepted: 20 December 2019; Published: 24 December 2019

\begin{abstract}
Brachiaria eruciformis (Sm.) Griseb. is a noxious weed of Australia and other parts of the world. The effects of different environmental conditions on the seed germination and seedling emergence of three biotypes sourced from different cropping systems (mungbean field, sorghum field, and fenceline) of this weed were evaluated. There were no differences in the response of biotypes to the evaluated factors; therefore, the data was pooled across the biotypes. The highest germination rate was observed at $30 / 20^{\circ} \mathrm{C}$, and seeds germinated both in light and dark conditions. Seed germination was influenced by different sodium chloride $(\mathrm{NaCl})$ concentrations and water potentials, and no seeds germinated at $200 \mathrm{mM} \mathrm{NaCl}$ and $-0.8 \mathrm{MPa}$ water potential. Seeds germinated $(>70 \%)$ at a broad range of $\mathrm{pH}$, from 4 to 10 . Compared with seeds sown on the soil surface, a burial depth of $4 \mathrm{~cm}$ reduced the seedling emergence by $84 \%$. Similarly, a sorghum residue amount of $4 \mathrm{t} \mathrm{ha}^{-1}$ on the soil surface reduced the seedling emergence by $65 \%$, compared with no sorghum residue cover. No seedlings emerged from seeds buried at $8 \mathrm{~cm}$ depth and $>4 \mathrm{tha}^{-1}$ sorghum residue. This study suggests that burying seeds deep into the soil through tillage or employing a residue cover on the soil surface can reduce B. eruciformis emergence.
\end{abstract}

Keywords: burial depth; $\mathrm{pH}$; salinity; sorghum residue and water deficit

\section{Introduction}

Brachiaria eruciformis (Sm.) Griseb. [synonym = Moorochloa eruciformis $(\mathrm{Sm}$.) Veldkamp or Panicum eruciforme Sm.; sweet summer grass or sweet signal-grass] is a noxious weed affecting cropping agricultural productivity in the tropic and subtropic zones of Africa, Americas, Asia, Australia, and some parts of Europe [1-6]. It is an annual grass belonging to the Poaceae family, which can be easily identified due to its red-purple leaf margins and leaf sheaths. This plant grows up to $60 \mathrm{~cm}$ high with a green leaf blade and simple and alternate leaves that are $10-15 \mathrm{~cm}$ in length. The small clump of this weed is slightly hairy and cylindrical [7-9].

Brachiaria eruciformis is spreading in the northern grain and cotton region (Queensland and New South Wales) of Australia [10], with a greater prevalence in central Queensland. Although a summer-dominant weed, this weed is often present in the late phase of winter crops and both in summer and winter fallows. It occurs in both cereals, particularly sorghum (Sorghum bicolor L.), and cotton (Gossypium hirsutum L.) systems [2,10]. This weed is a more significant problem in dryland cotton than in irrigated cotton [10]. 
Prolific seed production ( $>100,000$ seeds plant $^{-1}$ ), a short generation time with multiple cohorts in a season, and a high level of competitiveness are the main factors leading to the evolution of this species as a major weed [10]. In addition to competing with crops, it can develop a thick grass mat and interfere with harvest operations [7-9]. In 2011, this weed was rated as the number one weed with the potential to evolve resistance to the herbicide glyphosate [10] and has since developed resistance in some populations [11]. Despite a wide distribution of B. eruciformis in the northern region of Australia and its occurrence as a herbicide-resistant weed $[2,10,11]$, there is a lack of comprehensive knowledge on the management of this weed based on its germination biology. In terms of revenue loss, B. eruciformis is ranked the third weed in the northern grain region of Australia, accounting for a revenue loss of AU\$ 8.8 million annually, due to its prevalence in grain crops and fallows [12].

Weed adaptation to environmental conditions could be attributed to genetic diversity in weed populations that allows them to invade new areas [13,14]. Plants often adapt to habitat conditions such as temperature, water availability, light, and soil salinity. These conditions are the prime factors that decide weed germination, emergence, and establishment [15]. In addition, tillage and the presence of mulch on the soil surface are some of the management-driven aspects affecting weed germination and emergence [15-17]. Identifying the response of a weed species to burial or residue cover provides useful information for framing weed management options [15-17]. In many weeds, tillage leads to the burial of seeds deep into the soil, where emergence is inhibited [16]. Similarly, mulch application may also reduce the germination of photoblastic weed seeds by decreasing the availability of light [17]. A deeper understanding of how the maternal environment, human activity, and genetic diversity affects weed germination could help in developing accurate and reasonable management strategies to minimize the effect of weeds on crops and in predicting invasions in new areas.

Crop management affects the germination response of weeds [18,19]. For example, weeds maturing at the crop boundary seldom receive any tillage, fertilizer, or irrigation compared to those in crop fields. Such differences in management practices may select for changes in the germination characteristics of weed seeds [18-21] and need to be accounted for while making weed management decisions based on their germination ecology.

In this study, three biotypes of B. eruciformis were evaluated for their response to a range of environmental conditions so as to frame appropriate weed management options to suppress the further prevalence of this weed.

\section{Materials and Methods}

\subsection{Seed Collection}

Mature seeds were collected in April 2018 from a sorghum field $\left(27.56^{\circ} \mathrm{S}, 152.34^{\circ} \mathrm{E}\right)$, a mungbean field at Lawes $\left(27.54^{\circ} \mathrm{S}, 152.33^{\circ} \mathrm{E}\right)$, and a field boundary from Forest Hill $\left(27.59^{\circ} \mathrm{S}, 152.37^{\circ} \mathrm{E}\right)$ in the Queensland region. Seeds were collected by shaking mature plants over trays, were then cleaned and then stored in ambient conditions until the start of the experiment. Before starting the experiments, the seeds were cleaned again and X-rayed (Faxitron seed X-ray unit) to ensure that all seeds were filled (Figure 1A-C). Some species from the Brachiaria genus, including this one, have a hard coat [22]; therefore, seeds were scarified uniformly by spreading on a wooden table and by rubbing three times (10 $\mathrm{cm}$ up and down) using sand paper to break the physical seed dormancy. Germination improved after scarification (Figure 2). 


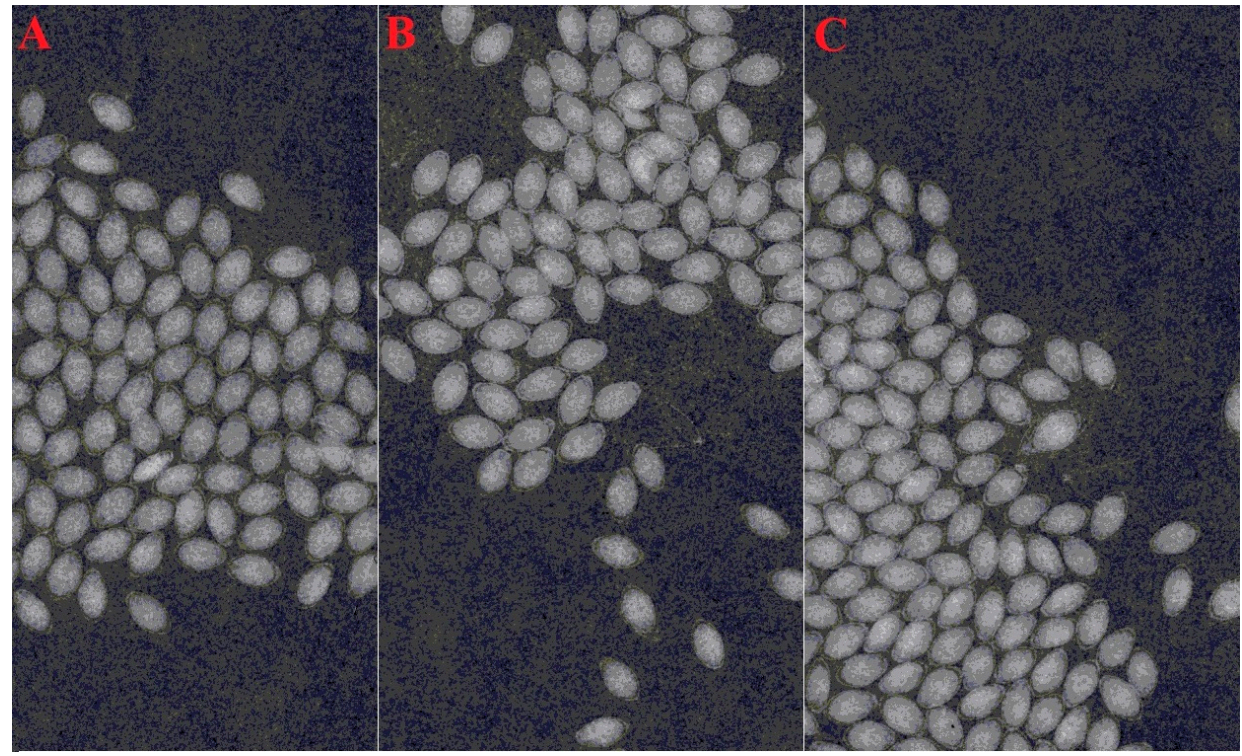

Figure 1. X-ray image of three biotypes of the Brachiaria eruciformis seed: (A) from a mungbean field, (B) from a sorghum field, and (C) from fencelines.

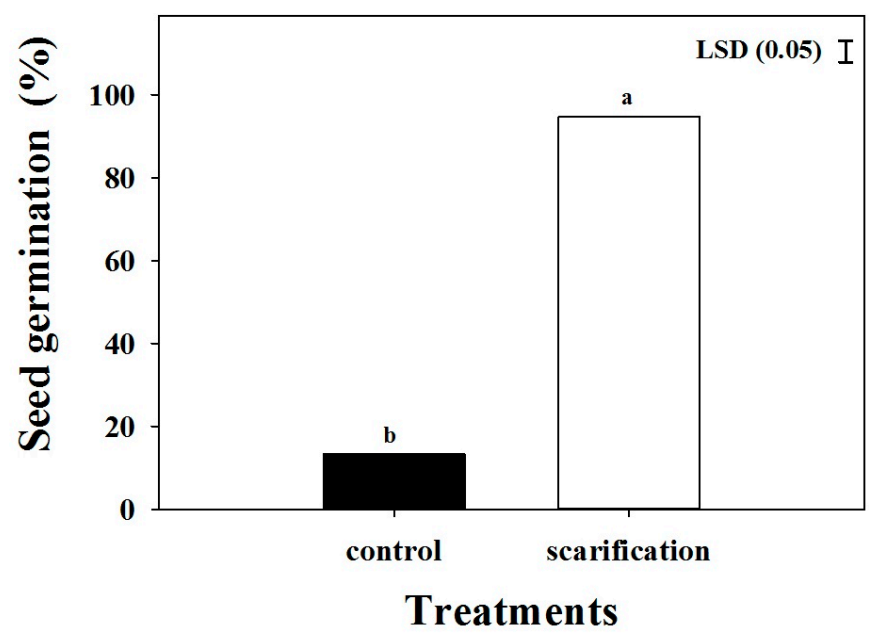

Figure 2. Effect of scarification with sand paper on the seed germination of Brachiaria eruciformis. Each bar of the graph represents a mean value of germination data (pooled across biotypes) as no significant differences were observed among biotypes. The vertical bar shows the least significant difference (LSD) values at the $5 \%$ level of probability.

\subsection{Common Procedure}

Experiments were conducted in 2018 to examine the effect of environmental factors on the seed germination of three biotypes of B. eruciformis in the weed science laboratory of Queensland Alliance for Agriculture and Food Innovation (QAAFI), The University of Queensland, Gatton, Australia. Twenty-five seeds were placed in 9-cm diameter Petri dishes on top of two layers of sterilized filter paper and moistened with water or other appropriate experimental solutions. Except for the temperature and light experiments, all experiments were conducted in an incubator set at 30/20 ${ }^{\circ} \mathrm{C}$ day/night temperature and a $12 \mathrm{~h}$ photoperiod. Further details on the temperature and light experiments are below. Seeds with a 2-mm radical were considered germinated, and the germination assessment was continued up to 28 days. Experiments were repeated after completing the first run. 


\subsection{Temperature and Light}

Five alternating day/night temperatures $\left(15 / 5,20 / 10,25 / 15,30 / 20\right.$, and $\left.35 / 25^{\circ} \mathrm{C}\right)$ in two light regimes [12 h photoperiod and complete darkness $(24 \mathrm{~h})]$ were used to determine the effect of temperature and light on germination. To avoid the penetration of light to seeds in the continuous dark treatment, Petri dishes were wrapped with three layers of aluminum foil. For the dark treatment, the seed germination counted only after 28 days.

\subsection{Water Potential, Salinity and $p H$}

To simulate the water potential and saline conditions in Petri dishes, appropriate solutions were selected. Water potentials (Polyethylene glycol, $\mathrm{C}_{2 \mathrm{n}} \mathrm{H}_{4 \mathrm{n}+2} \mathrm{O}_{\mathrm{n}+1}$ ) $[0$ (control), $-0.1,-0.2,-0.4$, $-0.6,-0.8$, and $-1 \mathrm{MPa}$ ] were prepared by using the method described by Michel and Radcliffe [23]. Salt concentrations were 0 (control), 25, 50, 100, 150, 200, and $250 \mathrm{mM}$, which were prepared by dissolving appropriate amounts of sodium chloride $(\mathrm{NaCl})$ in deionized water following the method of Poljakoff-mayber et al. [24]. To simulate alkaline and acid conditions in Petri dishes, buffer solutions $(4,5,6,7,8,9$, and $10 \mathrm{pH})$ were prepared according to Chachalis and Reddy [25]. All other conditions were constant, as mentioned in the common procedure section.

\subsection{Burial Depth and Sorghum Residue Amount}

Pots of $10 \mathrm{~cm}$ diameter $\times 12 \mathrm{~cm}$ height $(1 \mathrm{~L})$ were used to determine the effect of the sorghum residue amount and burial depth on the seedling emergence. The soil used in this experiment was collected from the Gatton Research Farm of the University of Queensland and had a $\mathrm{pH}$ of 7.1, organic matter of $2.4 \%$, nitrogen of $34 \mathrm{mg} \mathrm{kg}^{-1}$, phosphorus of $214 \mathrm{mg} \mathrm{kg}^{-1}$, and potash of $410 \mathrm{mg} \mathrm{kg}^{-1}$. To avoid the background seed bank of $B$. eruciformis, the soil was sieved and dried $\left(100^{\circ} \mathrm{C}\right)$ in an oven for $96 \mathrm{~h}$. The selected burial depths were 0 (soil surface), $0.5,1,2,4$, and $8 \mathrm{~cm}$. The sorghum residue was prepared by chopping ( $2 \mathrm{~cm}$ pieces) mature sorghum plants ( $c v$. MR Bazley) and placing the chopped pieces in an oven at $70^{\circ} \mathrm{C}$ for $96 \mathrm{~h}$. To examine the effect of the sorghum residue amount, seeds were placed on the soil surface and covered with dry sorghum crop residue at equivalent rates of $0,4,8,16$, and $32 \mathrm{tha}^{-1}$. Fifty seeds per pot were used, and the pots were placed in an incubator set at $30 / 20^{\circ} \mathrm{C}$ and sub-irrigated. Emerged seedlings were counted at a weekly interval over 28 days.

\subsection{Statistical Analyses}

All experiments were conducted twice. The data was pooled as there was no interaction between the experimental runs and treatments. A completely randomized design (Factorial $=$ biotype $\times$ treatment) with three replications was used for all tests. Before analyzing (ANOVA) (SAS software v. 9; SAS Institute, Cary, NC, USA) each experiment, the normality and homogeneity of variance (Shapiro-Wilk test) were tested, and no transformation was needed. For all treatments, the seed germination data was pooled across the biotypes, as no significant difference was observed among the biotypes $(\mathrm{n}=18)$. The effects of the scarification, temperature and light, $\mathrm{pH}$, burial depth, and sorghum residue on the germination of $B$. eruciformis were determined using the least significant difference test (LSD, $p \leq 0.05$ ). A three-parameter sigmoid model was used to describe the seed germination (\%) at different water potentials (Equation (1)):

$$
\mathrm{G}(\%)=\mathrm{Gmax} /[1+\exp (-(\mathrm{X}-\mathrm{X} 50) / \mathrm{b})]
$$

In this equation, $\mathrm{G}(\%)$ is the germination (\%) at water potential $\mathrm{X}, \mathrm{Gmax}$ is the maximum germination (\%), X50 is the water potential that caused a 50\% reduction in the seed germination, and $\mathrm{b}$ is the slope.

A three-parameter logistic model (Equation (2)) was used to model the salinity data following this equation:

$$
G(\%)=G \max /\left[1+(X / X 50)^{b}\right]
$$


where $\mathrm{G}(\%)$ is the germination (\%) at $\mathrm{NaCl}$ concentration $\mathrm{X}, \mathrm{Gmax}$ is the maximum germination (\%), $\mathrm{X} 50$ is the concentration of $\mathrm{NaCl}$ for a $50 \%$ inhibition of germination, and b shows the slope.

\section{Results}

\subsection{Scarification}

A poor germination $(<15 \%)$ was obtained in the control (no-treatment) condition (Figure 2). The germination improved $(p<0.001)$ by physical scarification. No difference was observed among the biotypes in response to the seed scarification.

\subsection{Temperature and Light}

The seed germination was significantly $(p<0.001)$ affected by alternating the temperature and light conditions, and their interaction produced a significant effect on the germination of $B$. eruciformis (Figure 3). There were no significant differences among the biotypes. Seed germination was not observed at $15 / 5{ }^{\circ} \mathrm{C}$ day/night temperature. The lowest germination was observed at $20 / 10{ }^{\circ} \mathrm{C}$, and germination was the greatest at day/night temperatures of $30 / 20^{\circ} \mathrm{C}$. Germination increased with an increasing temperature from $20 / 10$ to $30 / 20^{\circ} \mathrm{C}$. Increasing the temperature from $30 / 20$ to $35 / 25^{\circ} \mathrm{C}$ had a negative effect on the seed germination. Except at $25 / 35^{\circ} \mathrm{C}$, no significant differences were observed between the light/dark and dark treatments.

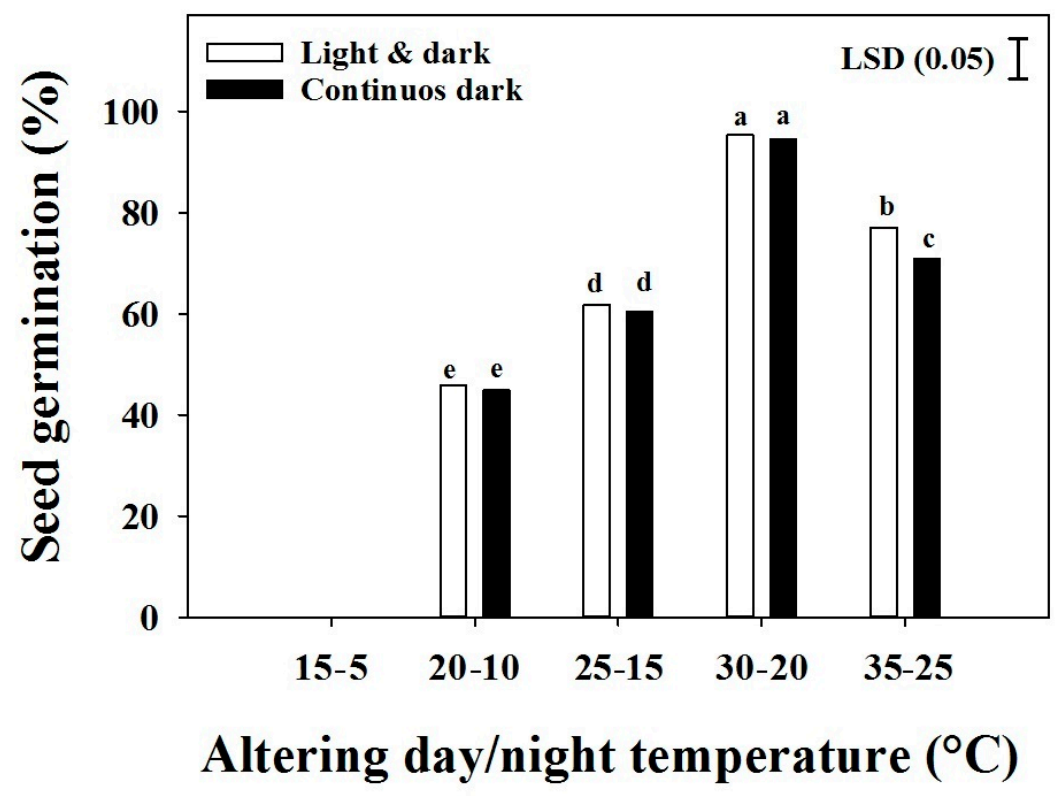

Figure 3. The effect of alternating the day/night temperature and light on the seed germination of three biotypes of Brachiaria eruciformis. Each bar of the graph represents a mean value of the germination data (pooled across biotypes), as no significant differences were observed among biotypes. The vertical bar shows the least significant difference (LSD) values at the $5 \%$ level of probability.

\subsection{Water Potential}

Germination was affected by different water potential levels (Figure 4). The effects of the treatments on the biotypes were not significant. Germination was reduced as the water potential decreased. The highest germination was observed for the control (0 MPa), and no germination was observed at the water potential $-0.8 \mathrm{MPa}$. The three-parameter sigmoidal model predicted a water potential of $-0.3 \mathrm{MPa}$ to inhibit a $50 \%$ germination (X50) of B. eruciformis. 


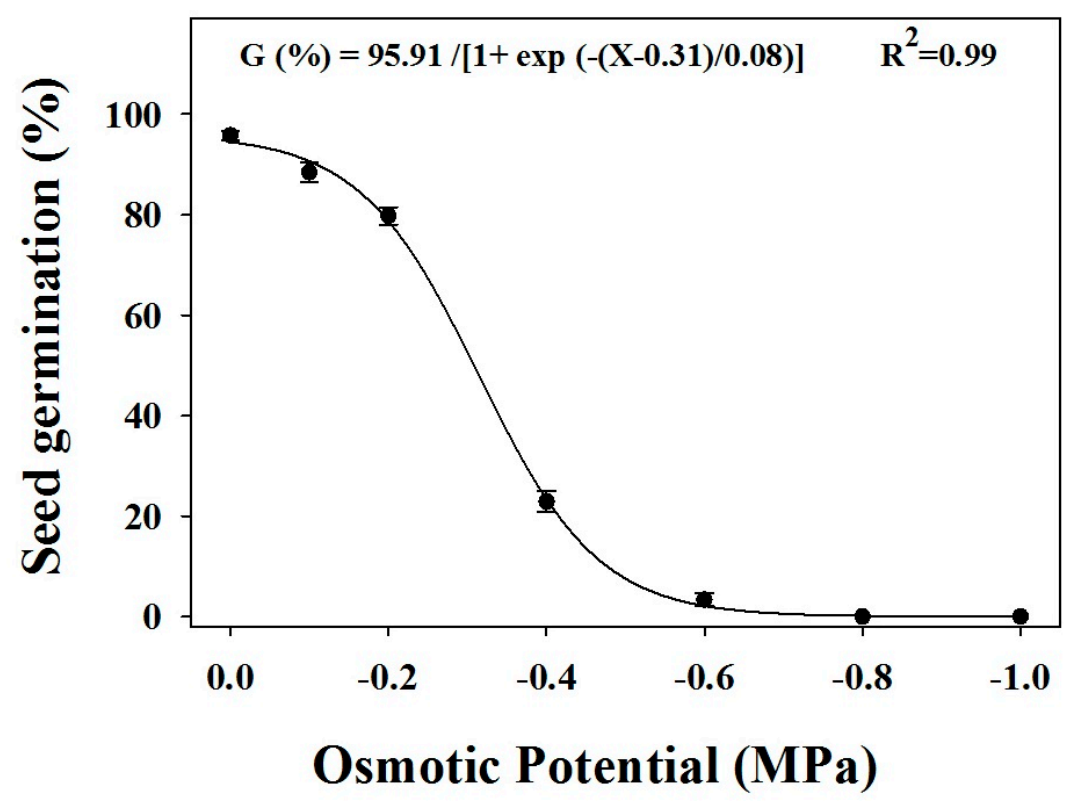

Figure 4. The effect of different osmotic potentials on the seed germination of three biotypes of Brachiaria eruciformis. Each point of the graph represents a mean value of the germination data (pooled across biotypes). A three-parameter sigmoid model was fitted to germination (\%). The vertical bars represented the standard error of mean.

\subsection{Salinity}

Different levels of $\mathrm{NaCl}$ concentrations caused significant differences in the germination of B. eruciformis (Figure 5). No significant differences were observed among the biotypes. Germination was the greatest at the control condition $(0 \mathrm{mM})$. Under increasing $\mathrm{NaCl}$ concentrations, the germination decreased, with $200 \mathrm{mM} \mathrm{NaCl}$ inhibiting the germination completely. $\mathrm{NaCl}$ concentrations of $85 \mathrm{mM}$ inhibited the germination by $50 \%$ (X50 value).

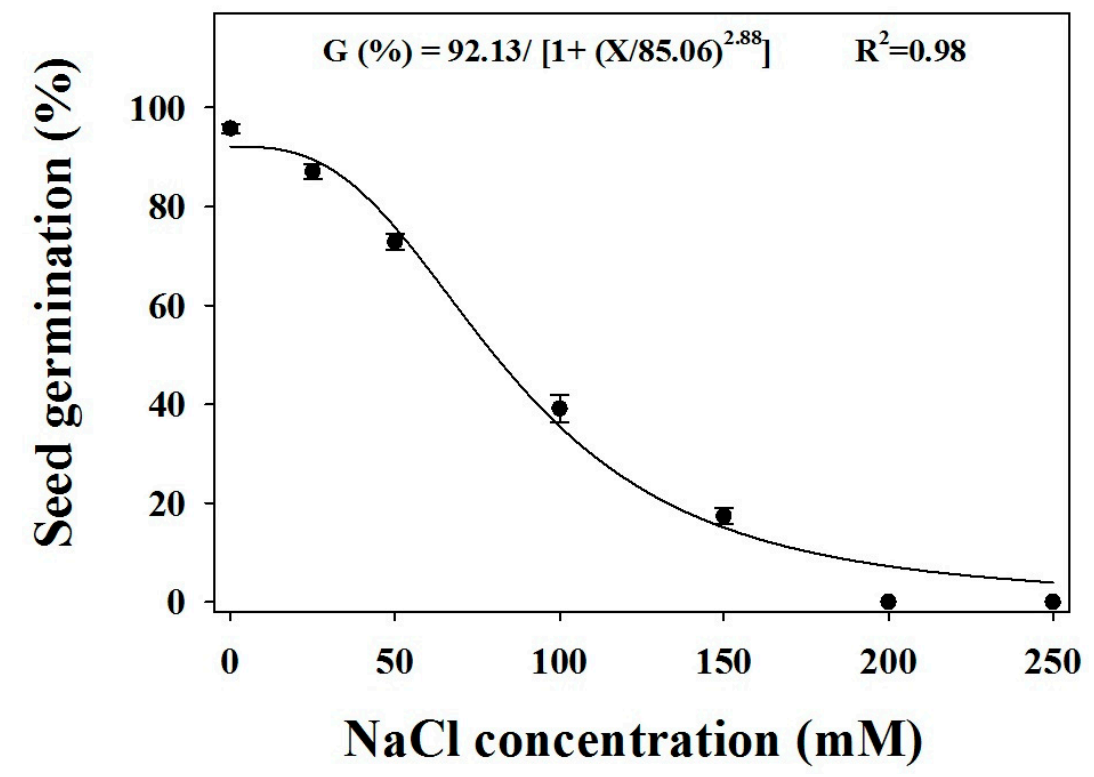

Figure 5. The effect of sodium chloride $(\mathrm{NaCl})$ concentrations on the seed germination of three biotypes of $B$. eruciformis. Each point of the graph represents a mean value of the germination data (pooled across biotypes), as no significant differences were observed among biotypes. A three-parameter logistic model was fitted to the germination (\%). The vertical bars represented the standard error of mean. 


\section{5. $p H$}

The germination of B. eruciformis was influenced by the $\mathrm{pH}(p<0.001)$ (Figure 6). The effect of the $\mathrm{pH}$ was similar among biotypes. The highest germination percentage occurred at a neutral $\mathrm{pH}$ condition (6-8), and seeds germinated more than $70 \%$ over the broad range of $\mathrm{pH}$ from 4 to 10 .

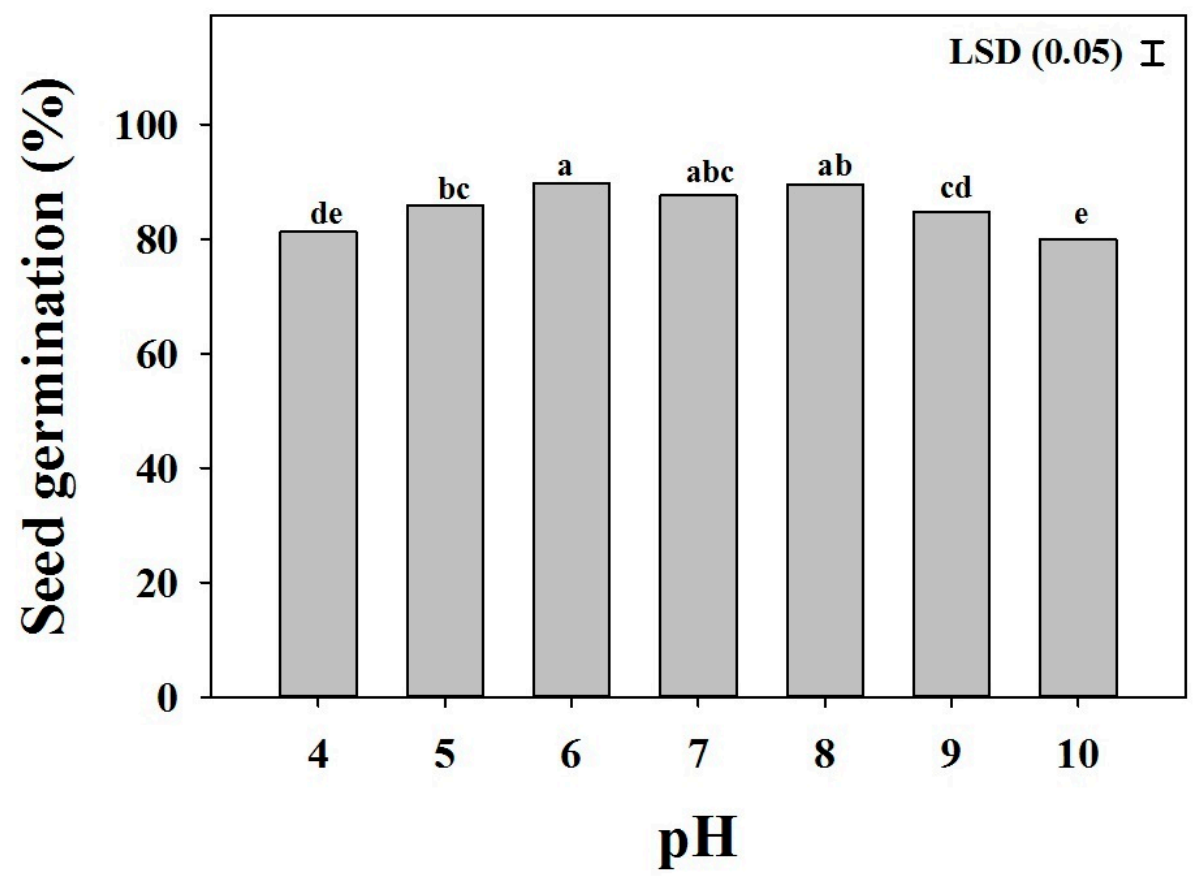

Figure 6. The effect of the $\mathrm{pH}$ level on the seed germination of three biotypes of Brachiaria eruciformis. Each bar of the graph represents a mean value of the germination data (pooled across biotypes), as no significant differences were observed among biotypes. The vertical bar shows the least significant difference (LSD) values at the $5 \%$ level of probability.

\subsection{Burial Depth}

The effect of the burial depth was significant $(p<0.001)$ for the seedling emergence of B. eruciformis (Table 1). No significant differences in the seedling emergence were observed among biotypes. The emergence of all biotypes decreased as the burial depth increased; there was a $>84 \%$ decrease in emergence from seeds buried 4 or more $\mathrm{cm}$ in comparison with a burial depth of $0 \mathrm{~cm}$. No seedling emergence was observed from $8 \mathrm{~cm}$.

Table 1. The effect of different burial depths on the seedling emergence of three biotypes of Brachiaria eruciformis. Each value of the table represents a mean value of the germination data (pooled across biotypes), as no significant differences were observed among biotypes.

\begin{tabular}{cc}
\hline Burial Depths (cm) & Emergence (\%) \\
\hline 0 & 63.4 \\
0.5 & 70.3 \\
1 & 55.2 \\
2 & 31.4 \\
4 & 9.9 \\
8 & 0.0 \\
LSD (0.05) & 1.93
\end{tabular}

LSD $(0.05)$ is least significant difference at $5 \%$ siginificance. 


\subsection{Sorghum Residue Amount}

The results showed that sorghum residue adversely influenced the emergence of $B$. eruciformis (Table 2). No significant differences were observed among biotypes in response to sorghum residue levels. The highest emergence was observed with the no sorghum residue treatment (63\%), while a sorghum residue amount of $>8 \mathrm{t} \mathrm{ha}^{-1}$ completely inhibited emergence.

Table 2. The effect of different sorghum residue amounts on the seedling emergence of three biotypes of Brachiaria eruciformis. Each value of the table represents a mean value of the germination data (pooled across biotypes), as no significant differences were observed among biotypes.

\begin{tabular}{cc}
\hline Sorghum Residue $\left(\mathbf{t ~ h a}{ }^{-\mathbf{1}}\right)$ & Emergence (\%) \\
\hline 0 & 63.4 \\
2 & 38.4 \\
4 & 20.8 \\
8 & 2.1 \\
16 & 0.0 \\
32 & 0.0 \\
LSD $(0.05)$ & 1.98 \\
\hline
\end{tabular}

\section{Discussion}

Brachiaria eruciformis is a native weed in tropical and subtropical zones of the world, and it has infested many agroecological regions [12]. The lack of germination at $15 / 5^{\circ} \mathrm{C}$ indicates the inability of this scarified weed seed to germinate under extreme winter conditions; however, more than $45 \%$ germination at $20 / 10^{\circ} \mathrm{C}$ shows the potential of this weed to germinate during the latter part of the winter season. In Queensland, unlike other growing regions, warm subtropical to tropical weather conditions exist with intermittent hot days even during the winter season. This study suggests the predominance of this weed in Queensland throughout the summer and late winter seasons and its potential to invade more areas of the northern region of Australia.

Similar germination responses to temperatures were observed in other weeds, such as Brachiaria platyphylla (Griseb.) Nash and Eleusine indica (L.) Gaertn, for which a cumulative germination increased with an increasing temperature, with the highest germination observed at $30 / 20{ }^{\circ} \mathrm{C}$ day/night temperature [26,27]. In the current study, biotypes responded similarly to changes in light and temperature conditions. In the dark condition, germination occurred across all temperatures. A similar germination pattern was observed in many weeds, including B. platyphylla and Poa annua L. [28,29]. The observation of germination in the dark condition explains the ability of $B$. eruciformis to germinate under a plant canopy or mulch. These results also suggest that this weed will germinate regardless of light conditions, allowing germination to occur even if it is buried at shallow depths.

Seed germination was not sensitive to varying $\mathrm{pH}$ levels. Seeds germinated more than $70 \%$ over a broad range of pHs from 4 to 10; however, the maximum germination was observed at the neutral $\mathrm{pH}$ condition (6-8). Similar results were observed in Lolium rigidum Gaudin [30], Chloris virgata Sw. [31], and Urochloa subquadripara Trin. [32]. Therefore, $\mathrm{pH}$ is not a restricting factor for the germination of B. eruciformis, allows this weed to adapt to several soil conditions, and provides the rationale for the wide distribution of B. eruciformis.

Brachiaria eruciformis could germinate between water potentials of 0 to $-0.6 \mathrm{MPa}$. With a decreasing water potential, germination was concomitantly reduced, and no germination was observed at $-0.8 \mathrm{MPa}$. Similar results were observed for Echinochloa colona (L.) Link. [33]. Persistence mechanisms such as the inhibition of germination under drought stress result in an induced dormancy until sufficient water is accessible for germination, consequently improving the ability for seeds to germinate once favorable conditions occur [34]. Although the northern cropping region receives ample summer rainfall, vagaries in rainfall are often observed, with fluctuations in the quantity and distribution of rainfall. Our results 
confirm those of other studies, which indicate the potential of this weed to emerge under a moderate level of water potential [33].

Similar to the water potential, salt stress can cause a reduction in germination. Our study indicates a high level of salt tolerance in B. eruciformis. Fifty percent of seeds were still able to germinate at $\mathrm{NaCl}$ concentrations of $85 \mathrm{mM}$, indicating that the salt tolerance is higher in B. eruciformis than in many other weeds. For example, the $\mathrm{NaCl}$ concentration that inhibited a 50\% germination in Rapistrum rugosum (L.) All. was $77 \mathrm{mM}$ [35]. The ability to germinate under high $\mathrm{NaCl}$ concentrations has been reported in many weeds, such as Chloris virgata Sw. and Eragrostis pilosa (L.) P. Beauv. [36], and this ability favors the distribution of the weed to new areas.

An increase in the burial depth and sorghum residue amount reduced B. eruciformis emergence. A burial depth of $4 \mathrm{~cm}$ and a sorghum residue amount of $4 \mathrm{tha}^{-1}$ reduced the emergence of B. eruciformis by $84 \%$ and $65 \%$, respectively. Reductions in the emergence of weeds due to an increase in the burial depth and residue amount have been reported for numerous weeds [37-39]. The low emergence of B. eruciformis with the increase in the burial depth and sorghum residue amount could be attributed to low seed carbohydrate reserves, the light requirement $[40,41]$, and could sometimes be due to allelopathy of the sorghum residue [42]. Light is not a restricting factor for B. eruciformis germination. Baskin and Baskin [43] noted that the emergence of small-seeded species with limited carbohydrate reserves was inhibited by deep burial in soil. Rather than spreading chaff (harvested crop straw and debris) into the entire field during crop harvest, the accumulation of chaff in line (chaff lining) is recommended so that the thick straw concentrated in line $\left(12\right.$ to $\left.40 \mathrm{t} \mathrm{ha}^{-1}\right)$ can minimize the emergence of weeds [9]. In this experiment, there was no emergence of this weed beyond $8 \mathrm{t} \mathrm{ha}^{-1}$ residue, indicating that maintaining straw to this magnitude through conservation agriculture practices or chaff lining can minimize the emergence of this weed. Tillage that can bury seeds more than $6 \mathrm{~cm}$ could be a good option for managing this weed. However, buried seeds with a long persistence in deep soil result in the accumulation of more seeds in the soil seed ban and keep the seeds safe from desiccation or predation [17]. B. eruciformis seeds have a hard seed coat and seem to remain in the soil for long periods; therefore, information on seed persistence is required to make management decisions.

\section{Conclusions}

The chosen biotypes from different cropping systems (mungbean and sorghum fields, and crop boundary) had no differences in their response to the evaluated factors on germination. It could be concluded that the germination ecology of B. eruciformis was mainly affected by the maternal environment, as the three biotypes were collected from the same region. None of the growing conditions had an inhibitory role or, rather, none favored the germination of one biotype over the others from a germination biology perspective. The ability to germinate over a broad range of environmental conditions could explain the wide distribution of this weed, and management options such as a thick residue cover may suppress the germination and emergence of this weed.

Author Contributions: A.M. collected data, analyzed data, and wrote the manuscript. M.M. collected data. S.M. collected data, reviewed and edited the paper. B.S.C. Conceptualization, performed design setup and supervision, resources, reviewed and edited the paper. All authors have read and agreed to the published version of the manuscript.

Funding: This research was funded by Grains Research and Development Corporation (GRDC), Australia, grant number UA00156.

Conflicts of Interest: The authors declare no conflict of interest. 


\section{References}

1. Quattrocchi, U. CRC World Dictionary of Grasses: Common Names, Scientific Names, Eponyms, Synonyms, and Etymology; CRC Press, Taylor and Francis Group: Boca Raton, FL, USA, 2006.

2. Osten, V.A.; Walker, S.R.; Storrie, A.; Widderick, M.; Moylan, P.; Robinson, G.R.; Galea, K. Survey of weed flora and management relative to cropping practices in the north-eastern grain region of Australia. Aust. J. Exp. Agric. 2007, 47, 57-70. [CrossRef]

3. Kumar, B. Brachiaria eruciformis. In The IUCN Red List of Threatened Species; IUCN: Gland, Switzerland, 2011. [CrossRef]

4. Acevedo-Rodríguez, P.; Strong, M.T. Catalogue of the Seed Plants of the West Indies. Smithson Contrib. Bot. 2012, 98, 1-1192. [CrossRef]

5. USDA-NRCS. The Plants Database. Available online: http://plants.usda.gov/ (accessed on 11 May 2018).

6. Council of Heads of Australasian Herbaria. Australia's Virtual Herbarium. Available online: http://www. chah.gov.au (accessed on 27 July 2019).

7. Stanley, T.D.; Ross, E.M. Flora of South-Eastern Queensland. Queensland Department of Primary Industries; Miscellaneous Publication: Canberra, Australia, 1989.

8. Wilson, B.J.; Hawton, D.; Duff, A.A. Crop Weeds of Northern Australia; Department of Primary Industries: Queensland, Australia, 1995.

9. GRDC. Weed Seeds Needed for Vital Research. Available online: www.grdc.com.au (accessed on 27 July 2019).

10. Werth, J.; Thornby, D.; Walker, S. Assessing weeds at risk of evolving glyphosate resistance in Australian sub-tropical glyphosate-resistant cotton systems. Crop Pasture Sci. 2012, 62, 1002-1009. [CrossRef]

11. Heap, I. International Survey of Herbicide Resistant Weeds. Available online: http://weedscience.org (accessed on 11 March 2019).

12. Llewellyn, R.; Ronning, D.; Clarke, M.; Mayfield, A.; Walker, S.; Ouzman, J. Impact of weeds in Australian grain production; Grains Research and Development Corporation: Canberra, ACT, Australia, 2016.

13. Lee, C.E. Evolutionary genetics of invasive species. Trends Ecol. Evolut. 2002, 17, 386-391. [CrossRef]

14. Geng, Y.; Van Klinken, R.D.; Sosa, A.; Li, B.; Chen, J.; Xu, C.Y. The relative importance of genetic diversity and phenotypic plasticity in determining invasion success of a clonal weed in the USA and China. Front. Plant Sci. 2016, 7, 213. [CrossRef]

15. Clements, D.R.; Ditommaso, A. Climate change and weed adaptation: Can evolution of invasive plants lead to greater range expansion than forecasted? Weed Res. 2011, 51, 227-240. [CrossRef]

16. Ren, J.; Tao, L.; Liu, X.M. Effect of sand burial depth on seed germination and seedling emergence of Calligonum L. species. J. Arid Environ. 2002, 51, 603-611. [CrossRef]

17. Chauhan, B.S.; Johnson, D.E. The role of seed ecology in improving weed management strategies in the tropics. Adv. Agron. 2010, 105, 221-262.

18. Brainard, D.C.; Ditommaso, A.; Mohler, C.L. Intraspecific variation in seed characteristics of Powell amaranth (Amaranthus powellii) from habitats with contrasting crop rotation histories. Weed Sci. 2007, 55, 218-226. [CrossRef]

19. Kleemann, S.G.L.; Gill, G.S. Differences in the distribution and seed germination behavior of populations of Bromus rigidus and Bromus diandrus in South Australia: Adaptations to habitat and implications for weed management. Aust. J. Agric. Res. 2006, 57, 213-219. [CrossRef]

20. Kleemann, S.G.L.; Gill, G.S. Seed dormancy and seedling emergence in ripgut brome (Bromus diandrus) populations in southern Australia. Weed Sci. 2013, 61, 222-229. [CrossRef]

21. Tungate, K.D.; Burton, M.G.; Susko, D.J.; Sermons, S.M.; Rufty, T.W. Altered weed reproduction and maternal effects under low-nitrogen fertility. Weed Sci. 2006, 54, 847-853. [CrossRef]

22. Renard, C.; Capelle, P. Seed germination in ruzizi grass (Brachaaria ruziziensis Germain \& Evrard). Aust. J. Bot. 1976, 24, 437-446.

23. Michel, B.E.; Radcliffe, D. A computer program relating solute potential to solution composition for five solutes. Agron. J. 1995, 87, 126-130. [CrossRef]

24. Poljakoff-Mayber, A.; Somers, G.F.; Werker, E.; Gallagher, J.L. Seeds of Kosteletzkya virginica (Malvaceae): Their structure, germination, and salt tolerance. II. Germination and salt tolerance. Am. J. Bot. 1994, 81, $54-59$. 
25. Chachalis, D.; Reddy, K.N. Factors affecting Campsis radicans seed germination and seedling emergence. Weed Sci. 2000, 48, 212-216. [CrossRef]

26. Burke, I.C.; Thomas, W.E.; Spears, J.F.; Wilcut, J.W. Influence of environmental factors on broadleaf signalgrass (Brachiaria platyphylla) germination. Weed Sci. 2003, 51, 683-689. [CrossRef]

27. Chauhan, B.S.; Johnson, D.E. Germination ecology of goosegrass (Eleusine indica): An important grass weed of rainfed rice. Weed Sci. 2008, 56, 699-706. [CrossRef]

28. Taylorson, R.B.; Brown, M.M. Accelerated after-ripening for overcoming seed dormancy in grass weeds. Weed Sci. 1977, 25, 473-476. [CrossRef]

29. Mcelroy, J.S.; Walker, R.H.; Wehtje, G.R.; Van Santen, E. Annual bluegrass (Poa annua) populations exhibit variation in germination response to temperature, photoperiod, and fenarimol. Weed Sci. 2004, 52, 47-52. [CrossRef]

30. Chauhan, B.S.; Gill, G.; Preston, C. Influence of environmental factors on seed germination and seedling emergence of rigid ryegrass (Lolium rigidum). Weed Sci. 2006, 54, 1004-1012. [CrossRef]

31. Fernando, N.; Humphries, T.; Florentine, S.K.; Chauhan, B.S. Factors affecting seed germination of feather fingergrass (Chloris virgata). Weed Sci. 2016, 64, 605-612. [CrossRef]

32. Teuton, T.C.; Brecke, B.J.; Unruh, J.B.; Macdonald, G.E.; Miller, G.L.; Ducar, J.T. Factors affecting seed germination of tropical signalgrass (Urochloa subquadripara). Weed Sci. 2004, 52, 376-381. [CrossRef]

33. Chauhan, B.S.; Johnson, D.E. Seed germination ecology of junglerice (Echinochloa colona): A major weed of rice. Weed Sci. 2009, 57, 235-240. [CrossRef]

34. Tobe, K.; Zhang, L.; Omasa, K. Seed germination and seedling emergence of three Artemisia species (Asteraceae) inhabiting desert sand dunes in China. Seed Sci. Res. 2006, 16, 61-69. [CrossRef]

35. Manalil, S.; Ali, H.H.; Chauhan, B.S. Germination ecology of turnip weed (Rapistrum rugosum (L.) All.) in the northern regions of Australia. PLOS ONE 2018, 13, e0201023.

36. Li, X.H.; Jiang, D.M.; Li, X.L.; Zhou, Q.L.; Xin, J. Effects of salinity and desalination on seed germination of six annual weed species. J. For. Res. 2011, 22, 475. [CrossRef]

37. Chauhan, B.S.; Manalil, S.; Florentine, S.; Jha, P. Germination ecology of Chloris truncata and its implication for weed management. PLoS ONE 2018, 13, e0199949.

38. Manalil, S.; Ali, H.H.; Chauhan, B.S. Germination ecology of Sonchus oleraceus L. in the northern region of Australia. Crop Pasture Sci. 2018, 69, 926-932. [CrossRef]

39. Iqbal, N.; Manalil, S.; Chauhan, B.S.; Adkins, S.W. Germination Biology of Sesbania (Sesbania cannabina): An emerging weed in the Australian cotton agro-environment. Weed Sci. 2019, 67, 68-76. [CrossRef]

40. Benvenuti, S.; Dinelli, G.; Bonetti, A. Germination ecology of Leptochloa chinensis: A new weed in the Italian rice agro-environment. Weed Res. 2004, 44, 87-96. [CrossRef]

41. Gardarin, A.; Dürr, C.; Colbach, N. Effects of seed depth and soil aggregates on the emergence of weeds with contrasting seed traits. Weed Res. 2010, 50, 91-101. [CrossRef]

42. Weston, L.A.; Alsaadawi, I.S.; Baerson, S.R. Sorghum allelopathy-From ecosystem to molecule. J. Chem. Ecol. 2013, 39, 142-153. [CrossRef]

43. Baskin, C.C.; Baskin, J.M. Seeds: Ecology, Biogeography, and Evolution of Dormancy and Germination; Academic Press: San Diego, CA, USA, 1998.

(C) 2019 by the authors. Licensee MDPI, Basel, Switzerland. This article is an open access article distributed under the terms and conditions of the Creative Commons Attribution (CC BY) license (http://creativecommons.org/licenses/by/4.0/). 